Laboratory. In addition to the maintenance of standards of measurement and testing of instruments and materials, much research work has been done on these subjects and on others submitted by industry. A noise meter and an instrument for measuring the penetration of daylight into rooms have been devised. Light magnesium alloys of greatly increased strength have been produced, and the eight wind tunnels have been in full use. The use of protective coatings on steels liable to corrosion and the reasons for the superiority of certain oils as lubricants are being investigated, while the ship testing tank has been requisitioned fo: 78 per cent of the merchant shipping constructed in Great Britain.

\section{Motion Pictures of Solar Prominences}

VoL. 3, No. 1 of Publications of the Observatory of the University of Michigan contains a detailed description by R. McMath of the tower telescope of the McMath-Hulbert Observatory which has recently been built near Lake Angelus, Michigan. The telescope, which comprises a modified form of spectroheliograph ("the spectroheliokinematograph"), has been used to take successful motion pictures of solar prominences. A specimen film, taken in $K_{2}$ light and showing various types of prominences, was recently exhibited at one of the monthly meetings of the Royal Astronomical Society. The gradual movements of comparatively stable prominences, the eruptive motions of others, and the frequent occurrence of descending streams of prominence matter from points of origin above the chromosphere were beautifully shown (The Observatory, 85, April 1937). It may be noted that the founders and designers of the Observatory and its equipment, R. R. McMath, H. S. Hulbert and F. C. McMath, are non-professional astronomers. Acknowledgment is made by them in the present memoir for assistance received in advice, expert supervision and financial assistance during the building of their tower telescope.

\section{The Zoological Society of London}

"The Zoo" progresses from strength to strength. A hundred years ago the then Earl of Derby announced that its income had mounted to $£ 19,123$; now it is $£ 154,172$; then the visitors numbered 363,392 , now they are $1,962,122$ plus another 484,453 at Whipsnade. The members who now number 8,307 were then 3,050 . The stock of animals has increased slightly more rapidly than the members, 3,867 as against 1,025 in 1837. One of the outstanding exhibits of the year (according to the report submitted to the annual general meeting on April 29) was a group of young Hainan gibbons, but the first giant forest hogs to reach any zoological garden and several white-tailed gnus, a species now extinct in a wild state, will arouse equal interest when they are shown to the public. The only important building erected during the year was the Studio of Animal Art, opened on April 21 by Lord Snell; but an innovation which obviously met a popular need was the launching of the Zoo magazine, the circulation of which has been maintained at close upon 100,000 copies.

\section{Dr. Marie Stopes's Coronation Ode}

IN his broadcast speech on Coronation Day, May 12, H.M. King George referred to the Royal office to which he has succeeded as the symbol of the constitutional link of Empire and to the service which he desired to render while occupying it. Dr. Marie Stopes has been inspired by the occasion to compose a lyrical poem in which she happily expresses these and other attributes of kingship as represented by his present Majesty. Four lines may be appropriately quoted here: they are :

Thou art the centre of a world-wide plan

To make new triumph out of world-worn things.

Thou art the symbol of a nation's pride,

The dazzling spear-point of an Empire's ran.

The ode has been attractively printed upon a card, and copies may be obtained from The Eclipse Press, 108 Whitfield Street, London, W.1, at the price of $1 d$. each or twenty for $1 s$.

\section{Jubilee Number of The Observatory}

THE inception sixty years ago of a monthly magazine, The Observatory, familiar in its blue covers to astronomers the world over, is commemorated in a special number, No. 755, of April 1937. The magazine was founded in 1875 by Sir William Christie, who was then Astronomer Royal, and it has been carried on voluntarily ever since, without any monetary grants whatsoever towards its publication, by successive editors, mainly from the observatory staffs at Greenwich and at Cambridge. The present number includes three special articles. In the first, Sir Frank Dyson reviews "Sixty Years of Meridian Astronomy." ; the second article is by Sir Arthur Eddington (himself one of the joint editors in 1913-19) who writes on "Interstellar Matter" ; while the third is from a veteran contributor (editor, 1893-1912), Mr. H. P. Hollis, whose article deals with Airy's water telescope. A unique feature of the past which found an appreciative circle of readers was the monthly anonymous contributions "From An Oxford Notebook" by the late Prof. H. H. Turner; these notes ran without a break from 1894 until Turner's death in 1930 . The current numbers of The Observatory carry on the useful work of providing a report of the discussions at the meetings of the Royal Astronomical Society (including Geophysical Discussions), in publishing articles by astronomers of international repute, and in airing views in the pages devoted to correspondence.

\section{Inland Water Survey}

Capt. W. N. McClean is publishing, in graphical form on standard sheets, the continuous record of water-levels, flows and storages, and of rainfall and temperature, for the Rivers Garry, Moriston and Ness, the three principal rivers of the Ness Basin of 700 square miles area. The records cover the period September 1929 to the end of the year 1935, and are obtainable in separate sheets or as a complete series for each river in a portfolio. The river survey work has been organized and carried out by the staff of River Flow Records, under the direction of 